\title{
Duygusal Zekânın, Yaşam Doyumu ve Akademik Başarıya Etkileri ve Demografik Özellikler Bağlamında Algı Farklılıkları
}

\author{
İsmail BAKAN* Bilge GÜLER* \\ *Kahramanmaraş Sütçü İmam Üniversitesi, İktisadi ve İdari Bilimler Fakültesi, İşletme Bölümü, Kahramanmaraş
}

\begin{abstract}
Özet
$\mathrm{Bu}$ çalışmanın amacı; bireylerin üniversite öğrenciliği dönemindeki yaşam doyumunun ve akademik başarısının gelecekteki hayatını önemli derecede etkilediği düşüncesiyle öğrencilerin sahip oldukları duygusal zekâlarının yaşam doyumuna ve akademik başarılarına etkilerini incelemektir. Ayrıca duygusal zekâ ve yaşam doyumunun bireylerin okudukları bölüm ve bazı demografik özelliklere göre anlamlı bir farklılık gösterip göstermediğini tespit etmektir. Bu amaçla İktisadi ve İdari Bilimler Fakültesi İşletme, İktisat, Kamu Yönetimi ve Uluslararası İlişkiler bölümü 3. ve 4. sinıfında okumakta olan 437 öğrenciye anket uygulanmıștır. Anket uygulaması sonucu elde edilen veriler SPSS programı kullanılarak; T-Testi, ANOVA, korelasyon ve regresyon analizleriyle test edilmiştir. Yapılan analiz sonuçlarına göre; duygusal zekanın öğrencilerin yaşam doyumlarını etkilediği görülürken, akademik başarılarını etkilemediğ belirlenmiştir. Öğrencilerin okudukları bölümlerine bağlı olarak yaşam doyumları arasında anlamlı farklılıklar oluşurken, duygusal zekâları ile anlamlı farklılık olmadığı görülmüsstür. Buna göre, işletme bölümü öğrencilerinin yaşam doyumları, kamu yönetimi bölümündeki öğrencilere nazaran daha yüksek çıkmıştır. Demokratik bir tutum sergileyen ailelerin de yaşam doyumunu etkilediği sonucuna ulaşılmıştır. Ancak ögrencilerin ailelerinin tutumları duygusal zekaları ile karşılaştırıldığında anlamlı bir farklılık görülmemiştir. Bunların yanı sıra öğrencilerin anne baba medeni durumu, en uzun süre yaşadığı yer, sınıfı ve öğretim türüne göre duygusal zekaları ve yaşam doyumları farklılaşmamaktadır. Fakat cinsiyete göre duygusal zekanın farklılaştığı görülmüş̧ür.
\end{abstract}

Anahtar Kelimeler: Duygusal Zekâ, Yaşam Doyumu, Akademik Başarı, Üniversite Öğrencileri

\section{The Effects of Emotional Intelligence on Life Satisfaction and Academic Success and Perception Differences in the Context of Demographic Characteristic}

\begin{abstract}
The purpose of this study is to examine the effects of emotional intelligence of students on their life satisfaction and academic success with the thought that life satisfaction and academic success of individuals when they are student at a university affect significantly their future life. It is also aimed to determine whether emotional intelligence and life satisfaction differ significantly according to the individual's departments and some demographic characteristics. For this purpose, a questionnaire was administered to 437 students who are at 3rd and 4th grade of Business Administration, Economics, Public Administration or International Relations departments in faculty of Economics and Administrative Sciences. Obtained data were tested by T-Test, ANOVA, correlation and regression analysis through SPSS program. According to the results of the analyzes; it was determined that while the emotional intelligence affect life satisfaction of students, it does not affect academic achievement. It was seen that there was no significant difference in the emotional intelligence while there were significant differences between life satisfaction according to the students' departments. According to these results, life satisfaction of students in business administration department is higher than students in the public administration department. It has been achieved that the families who demonstrate a democratic attitude also affect life satisfaction. However, no significant difference was observed when the emotional intelligence was compared based on the attitudes of the students' parents. Besides these, there is no difference in the emotional intelligence and life satisfaction according to the marital status of parents, the place where students live longest, the class and type of education of students while it has been observed that emotional intelligence differs according to gender.
\end{abstract}

Keywords: Emotional Intelligence, Life Satisfaction, Academic Success, University Students

\section{Giriş}

Bireyin hem kendi duygularını hem çevresindeki insanların duygularını doğru bir şekilde anlayıp değerlendirebilmesi ve duygularını istediği şekilde yönlendirip davranışa dönüştürmesi olarak ifade edilen duygusal zeka hakkında yapılan bazı araştırma sonuçlarına göre; duygusal zeka yaşamdan doyum sağlamada ve yaşamın diğer tüm alanlarında başarıyı yakalamada IQ ile ölçülen zeka kadar önemlidir (Tekin Acar, 2002: 54). Goleman da (1995: 34) duygusal zekanın yaşamda başarıyı yakalamada IQ'dan daha güçlü bir rol oynadığını belirtmiştir.

Duyguların bilişsel süreçlere uyum sağladığını ve bireylerin duyguları hakkında rasyonel olarak düşünebileceğinin aksini öngören duygusal zeka kuramı (Brackett et al., 2011: 89); kişinin arzu ettiği yönde kendini harekete geçirebilmesi, önüne çıkan engellere ve aksiliklere rağmen istediği yönde ilerlemesi, duygularını kontrol etmesi ve ruh halini kontrol altında tutup düzenleyebilmesi, karşılaştığ1 zorlukların üstesinden gelmesi, başkalarını anlaması ve empati kurabilmesi ve tüm bunları yaparken umut içinde olmayı desteklemektedir. (Goleman,1995: 62). Bireyin tüm bunları başarmasında duygularını iyi bir şekilde yönetebilmesi önem taşımaktadır. Duygularını arzu ettiği yönde yönetip hedefine ulaşmaya çalışan üniversite öğrencisinin yaşam doyumu bu durumdan etkilenecektir. Yaşam doyumu kişinin kendi koyduğu kriterlere göre yaşam koşullarını algılayışı ve buna bir değer yüklemesidir. Bu anlamda bireyin sahip olduğu duygusal zekası yaşam doyumunu etkileyecektir.

Günümüzde gelişimi yakalamak ve sürekli ilerleyebilmenin yolu yaratıcı, üretken, orijinal fikirler sunan, farklılıkları görebilen ve yönetebilen, sürekli öğrenmeyi ve 
kendini geliştirmeyi amaç edinensorumluluk sahibi bireylere sahip olmaktan geçmektedir (Köknel, 1998: 82). Karşılaşacağı zorluklarla başa çıkabilen, başkalarını anlayan, topluma faydası olan, empati kurabilen ve çözüm odaklı olan duygusal zekaya sahip bireylerler toplumun geleceği için son derece önemlidir. Bireyin üniversite öğrenciliği döneminden itibaren duygusal zekasını kullanabilmesinin onun yaşam doyumunu ve akademik başarısını etkileyebileceği düşüncesi çerçevesinde bu çalışmada; duygusal zekanın yaşam doyumu ve akademik başarıya olan etkileri incelenmektedir. Ayrıca duygusal zeka ve yaşam doyumunun bireylerin okudukları bölüm ve bazı demografik özelliklere göre anlamlı bir farklılık gösterip göstermediği test edilmiştir.

\section{Kavramsal Çerçeve}

\subsection{Duygusal Zekâ}

1986 yılında WaynePayne tarafindan ilk defa ortaya atılan bu kavram yazında 1990 yılında Salovey ve Mayer'in çalışmaları sonucu kullanılmaya başlanmıştır (Çapraz et al., 2009: 195). Bu tarihten sonra ise 1995 y1linda Daniel Goleman'ın "Duygusal Zeka Neden IQ'dan Önemlidir" adlı kitabı ile duygusal zeka kavramı yaygınlaşmaya ve akademik örgütlerin dışına da yayılmaya başlamıştır (Çakar ve Arbak, 2004: 34).Goleman (1995) bu kitabında duygusal zekâyı; "bireyin kendisini harekete geçirebilme, aksiliklere rağmen yoluna devam edebilme, dürtüleri kontrol ederek tatmini erteleyebilme, ruh halini düzenleyebilme, empati kurma, umut etme, sorunların düşünmeyi engellemesine izin vermeme" olarak tanımlamıştır.

Bazı yazarlar tarafından çeşitli şekillerde tanımlanan duygusal zekâ kavramları aşağıdaki gibidir;

- Duygusal zeka, kendi ve başkalarının duygularının gücünü doğru bir şekilde sezme, anlama ve duyguları etkili bir şekilde kullanıp ona yol gösterme kabiliyetidir (Cooper ve Sawaf, 2003: 377).

- Toktamışoğlu'na göre (2003: 79) duygusal zeka; kişiler arasında daha güçlü bir iletişimi sağlamak için duyguları, hisleri, sezgileri etkin bir şekilde kullanmak ve yönetmektir.

- Duygusal zeka, kognitif ve duygusal gelişim için düşünceye yol gösterecek ve yardım edecek şekilde duyguları doğru bir şekilde anlama ve bunları hedefe yönelik olarak düzenleyebilme ve kontrol altına alma kabiliyetidir (Mayer et al., 2004: 197).

- Goleman'a göre (2005: 50) duygusal zeka, bireyin amaçları doğrultusunda güdülenmesi, önüne çıkan engellere rağmen ilerleyebilme gücü, kendi duygularının kontrolünü sağlayarak sıkıntıları aşması, başka insanları anlaması ve psikolojik sermayesini pozitif olarak kullanabilmesi kabiliyetidir.

- Druskat'a göre (2006: 28) duygusal zeka; mutlu bir ruh hali için duyguları doğru olarak değerlendirip anlatma ve onu amaçlanan yönde kullanabilme yeteneklerini içermektedir.

- Memduhoğlu ve Yılmaz (2010: 150) tarafindan duygusal zeka, kişinin hem kendi hem başkalarının duygularını doğru bir şekilde algılaması ve bu duyguları ifade etmesi sonrasinda ise bu duygular arasında ayrımı yapıp bunu insanlarla ilişkisinde kullanabilme kabiliyeti olarak ifade edilmiştir.
Sonuç itibariyle kişisel yetenekler ve sosyal yetenekler olmak üzere iki temel boyut üzerine odaklanan (Parthasarathy, 2009: 32) duygusal zeka, kişinin hem kendini hem etrafında iletişim içinde olduğu insanları tanıyabilmesi, bu sayede hem kendi hem çevresindeki insanların duygusunu doğru olarak algılaması ve bu duyguları etkili olarak değerlendirebilmesi ve istenilen şekilde yönlendirip kontrol sağlama yetenekleri toplamıdır (Gürbüz ve Yüksel, 2008: 176). Fakat bu tanımlarla birlikte duygusal zeka duygu ile zekayı bir araya getirdiğinden dolayı zıtlıkları içermektedir. $\mathrm{Bu}$ zıtlığın sebebi ise; zekanın rasyonel düşünce ile tanımlanması iken duyguların rasyonel kararlar içermeyen düşünce ve davranışları barındırmasıdır (Matthews et al., 2002: 7).

Farklı duygusal zekâ tanımlamalarının yanı sıra bazı yazarlar duygusal zekânın boyutlarını da farklı açılardan ele almış ve çeşitli duygusal zekâ modelleri geliştirmişlerdir. Bu araştırmada kullanılan duygusal zekâ modeli Wong ve Law'ın (2002), Davis ve arkadaşlarının (1998) yaptığı dört boyuttan oluşan duygusal zekâya dayanan ölçek modelidir. Ölçeğin dört alt boyutu ise şunlardır: Kendi Duygularını Değerlendirme, Başkalarının Duygularını Değerlendirme, Duyguların Kullanımı ve Duyguların Düzenlemesidir (Ng, 2007: 178)

Kendi Duygularını Değerlendirme; bireyin kendi derin ve içsel duygularını anlaması, kendini tanıması ve duygularını kolay bir şekilde ifade edebilme kabiliyetidir. Başkalarının Duygularını Değerlendirme; bireyin çevresindeki kişilerin duygularını anlaması, empati kurabilmesi ve başkalarına yardımcı olacak şekilde onların duygularını yönlendirebilme yeteneğidir. Duyguların Kullanımı; istenen amaç doğrultusunda duyguları harekete geçirerek onları başarıya ulaștıracak davranışa dönüştürme kabiliyetidir. Kiși duygularını etkili bir şekilde kullanması ile olumsuz ruh halini olumlu ruh haline çevirerek amaçladığı sonuca ulaşır. Duyguların Düzenlemesi boyutu ise; bireylerin ruh halini kontrol altına alıp, sıkıntı yaşadığı durumlarda duygusunu düzenlemesi veya pozitif hale dönüştürmesi ile ilgilidir. Böylece duygularını düzenleyen bireyler gerektiğinde davranışlarını kontrol altına alıp amaçladığı sonuca ulaşmayı kolaylaştırabilirler (Davies et al., 1998, aktaran, Wonget al., 2004: 536). Tüm bunlar için bireyin kendini motive edebilmesi önemlidir. Kendini motive edebilmek, bireyin karşısına çıkan zorluk ve engellere rağmen hatta başarısızlıklara rağmen bile amaçlara bağlı kalıp mücadele etme, yenilikler ve değişikliklere uyum sağlayıp beraber yol alma yeteneğini gerektirmektedir (Rahim ve Psenicka, 2002: 305).

\subsection{Yaşam Doyumu}

1961 y1lında ilk defa Neugarten, Havinghurst ve Tobin adlı yazarlar tarafından yaşam doyumu, bireyin bir şeydenbeklentisi sonucu elde ettiği ile arzusunu karşılaştırması sonucu duyduğu haz, mutluluk olarak tanımlanmıştır.

Bireyin yaşadığı hayata yüklediği anlam, hedeflere ulaşma, kişilik yapısı, ruh hali, ekonomik durum, çevreye uyum ve sosyal ilişkiler gibi birçok faktörden etkilenen ve kişiden kişiye farklılık gösteren yaşam doyumu kavramı genel olarak bireyin yaşamı karşısında hissettiği pozitif duygusal tepkiler olarak ifade edilebilir ve yaşamdan memnuniyet derecesi ile ilgilidir (Sung-Mook ve 
Giannakopoulos, 1994, Schmitter, 2003, aktaran, Recepoğlu, 2013: 314). Bu faktörlerin yanı sıra yaşam doyumunun bireylerin sahip oldukları duygusal zekâlarından da etkilendiği daha önceki sınırlı sayıda yapılan araştırmalarda (örneğin, Ergin ve ark., 2013; Deniz ve Y1lmaz, 2004) görülmüştür. Kişilerin, geliştirilebilir yeteneklerden oluşan duygusal zekâlarını başta eğitim hayatı olmak üzere hayatlarının her alanında kullanması hem yaşam doyumlarında hem akademik başarılarında artış sağlayacaktır.

Duygusal zeka, bireyin tüm yaşamını etkileyen ve yönlendiren bir kavramdır. Ayrıca sadece çalışma hayatında değil bireyin tüm hayatında başarıya ulaşmasında son derece önemlidir. Bireyin yaşamında başarıya ulaşması ise mevki, para ve kariyere sahip olması değil sahip olduklarından mutlu olup, kendini ruhsal olarak iyi hissetmesi ve yaşamından keyif almasıdır (Doğan, 2005: 114). Yani bireyin başarılı olması duygusal zekâsını kullanarak yaşam doyumu sağlamasına bağlıdır. Bu nedenle duygusal zekâ ile yaşam doyumu birbirlerine bağlı, birbirleri ile etkileşim içinde olan iki önemli kavramdır.

\subsection{Akademik Başarı}

En genel anlamda başarı, bireyin öğrenim hayatı boyunca eğitim ortamında aldığı derslerin bireye olan faydasının bir göstergesi olarak tanımlanırken eğitimde başarı ise; okullarda verilen derslerde bireyin başarı durumunun öğretmenler tarafindan somut delillere çevrilerek notlarla ifade edilmesi ya da öğrencinin kendine olumlu yönde kattıklarının karşılığı olan "Akademik Başarı" olarak tanımlanabilir (Carter ve Good, 1973, aktaran, Keskin ve Sezgin, 2009: 5).

Öğrencilerin okul hayatları boyunca kendine kazandırdıklarının toplamından oluşan akademik başarı, en somut şekliyle öğrencinin okutulan derslerden aldığı notlar ve bunlar sonucu oluşan ağırlıklı genel not ortalamasının hesaplanması yolu ile değerlendirilir. Derslerden alınan notlar, öğrencinin o ders ile ilgili performansını göstermektedir (Green, 2000: 24). Akademik başarı, öğrencilerin başarılarını değerlendirmeye yardımcı olan başarı ölçütlerinden biri olup öğrencinin eğitimi boyunca karşılaştığı durumlardan ve bireyin zekas1, yaşı vs. gibi kişisel bazı özelliklerden etkilenmektedir (Karakaş, 1981, aktaran, Kenarlı, 2007: 45).

Duygusal zekanın da bireyin akademik başarısını etkileyen faktörler arasında olduğu daha önce yapılan çalışmalarca (örneğin, Kavcar, 2011; Üzel ve Hangül, 2011) tespit edilmiştir. Duygusal zeka ile akademik başarıyı ilk ilişkilendiren yazar olan Goleman'a göre; duygusal zekaya sahip olan öğrenciler başarılı olmalarına katkı sağlayan kendini güdüleme yeteneğine ve psikolojik sermaye unsurlarından umut, iyimserlik gibi başarıya ulaşmalarını kolaylaştıran yeteneklere sahiptirler. Bunun yanı sıra duygusal zekaya sahip öğrenciler akademik hayatlarında karşılaştıkları baskılara ve zorluklara karşı daha az kaygılıdırlar (Drago, 2004: 12). Öğrencinin yüksek bir duygusal zeka düzeyine sahip olması, yani hem kendi duygularını hem çevresindeki insanların duygularını anlaması ve iyi analiz etmesi, duygularını amacına yönelik olarak kullanması ve yönetmesi yeteneği sonucu öğrencinin güdülenme gücü artacağından ve çevresi ile iletişimi güçleneceğinden dolayı herkes tarafından sevilir ve dolayısıyla iyi bir okul tecrübesi yaşar ve bu da öğrencinin akademik başarısını olumlu etkileyebilir. Öğrencinin duygusal zekasının düşük olduğu bir durumda ise tam tersi olaylar gerçekleşebilir ve öğrencinin akademik başarısı bundan olumsuz olarak etkilenebilir (Holt, 2007: 17). Bu anlamda bireyin yüksek duygusal zeka düzeyine sahip olması önemlidir.

Öğrencilerin tüm yaşamını önemli oranda etkileyen akademik başarı, hem birey açısından hem de bireyin içinde yaşadığı toplum açısından son derece önemlidir. Amaçlarına güdülenen, kendini motive edebilen, karşılaştığı zorluklarla baş edebilecek, başarıyı temel koşul olarak alıp kendini geliştiren ve yenileyen, bilgilerle donanmış akademik açıdan güçlü bir öğrenci toplumun yükselmesinde en önemli güç faktörüdür. Akademik başarısızlık söz konusu olduğunda ise yine bu durumdan hem birey hem de toplum etkilenecektir. Bireyin okul hayatında çeşitli nedenlerle yaşadığı akademik başarısızlığı, okuldan istediği verimi alamamasına yol açacak, bireyi okulu terk etme sıkıntısı ile karşı karşıya bırakacak ve dolayısıyla geleceğin nitelikli insan gücü sayısı azalacaktır (Keskin ve Sezgin, 2009: 5). Bunun yanı sıra bireylerin akademik başarısızlıkları yaşam doyumlarını ve motivasyonlarını da olumsuz etkileyecektir. Duygusal zekâ, bireylerin hedeflerine ulaşmasında, zorluklarla baş etmesinde, duygularını kontrol etmesinde onlara yardımcı olacağından dolayı bireyler bu başarısızlıkları duygusal zekalarını geliştirerek aşabilir.

Literatürde, duygusal zeka ile akademik başarı arasındaki ilişkiyi inceleyen araştırmalar bulunmaktadır. Kavcar'ın (2011) üniversite öğrencileri, Üzel ve Hangül'ün (2011) ise ilköğretim öğrencileri üzerinde yaptıkları araştırmalarda, öğrencilerin duygusal zekaları ile akademik başarıları arasında anlamlı ilişkiler olduğu bulgusuna ulaşmışlardır.

Dost (2007), Hacettepe Üniversitesi'nde 403 öğrencinin katılımı ile yaptığı çalışmada öğrencilerin yaşam doyumlarının algıladıkları akademik başarılara göre farklılaştığını belirlemiştir. Buna göre, akademik başarısını yüksek düzeyde algılayan bireylerin yaşam doyumlarının da daha yüksek olduğu sonucuna ulaşmıştır. Çivitci (2012) ise yaptığı çalışmada, yaşam doyumu yüksek olan öğrencilerin başarı ihtiyaçlarının da daha yüksek olacağını belirtmiştir.

$\mathrm{Bu}$ çalışmaların da gösterdiği gibi duygusal zeka, yaşam doyumu ve akademik başarı birbirlerine bağlı ve birbirlerinden etkilenen kavramlardır. Öğrencilerin duygusal zekalarını geliştirmesi yaşam doyumlarını arttıracak, yaşam doyumu artan bireyin ise başarı ihtiyacı yükseleceğinden akademik başarısı artabilecektir.

Yerli ve yabancı literatürde duygusal zeka, yaşam doyumu ve akademik başarı ilişkisini özellikle üniversite öğrencileri üzerine inceleyen sınırlı sayıda çalışmaya rastlanmıştır. $\mathrm{Bu}$ çalışma İIBF İşletme, İktisat, Kamu Yönetimi ve Uluslararası ilişkiler öğrencileri üzerine yapılması bakımından önem taşımaktadır. Daha önce bu dört bölümün öğrencilerinin duygusal zekalarının yaşam doyumu ve akademik başarıya etkilerini karşılaştırmalı olarak inceleyen bir çalışmaya rastlanmamıştır.

Toplumun kalkınmasında önemli role sahip olan ve geleceğin gençlerini yetiştiren üniversiteler, öğrencilerin duygusal zekalarının gelişimi için gereken özenigöstermelidirler (Y1lmaz, 2007: 51). Duygusal zeka geliştirilebilir bir özellik taşıdığından dolayı; üniversitede verilen eğitim sayesinde bireyler duygusal zekalarını 
geliștirebilir ve bu da yaşam doyumlarını ve akademik başarılarını olumlu yönde etkileyebilir.

Gençliğinin baharını yaşayan üniversite öğrencileri için yaşam doyumu son derece önemlidir. Bireyler duygusal zekaları ile karşılaştığı zorlukları, engelleri, olumsuz koşulları pozitif hale dönüştürerek yaşam doyumlarını arttırabilirler. Bu anlamda bireyin duygusal zekası yaşam doyumunun artmasında önem taşımaktadır. Duygusal zekasını kullanabilen bireyin yaşam doyumu olumlu etkileneceğinden üniversitedeki akademik başarısı da bu durumu etkileyebilir ve bireyin gelecek yaşamını yönlendirmesi ve şekillendirmesi daha çok kolaylaşabilir.

\section{Araştırmanın Metodolojisi}

$\mathrm{Bu}$ bölümde araștırmanın amacı ve önemi, evreni ve örneklemi, yöntemi ve hipotezleri açıklanmıştır.

\subsection{Araştırmanın Amacı ve Önemi}

$\mathrm{Bu}$ çalışmanın temel amacı; öğrencilerin duygusal zekalarının, yaşam doyumu ve akademik başarıları üzerindeki etkilerini incelemektir.

Literatürde öğrencilerin duygusal zekalarının yaşam doyumu ve yaşam doyumunun da akademik başarılarına etkilerini ayrı ayrı inceleyen araştırmalar az sayıda da olsa bulunmakla birlikte, duygusal zekanın yaşam doyumu ve akademik başarı üzerindeki etkilerini bir arada inceleyen özellikle İIBF öğrencileri üzerine yapılan bir araştırmaya rastlanılmamıştır. Duygusal zeka, yaşam doyumu ve akademik başarı kavramları birbirlerine bağlı olan ve birbirleri ile yakın ilişki içerisinde olan kavramlardır ve birbirlerinden etkilenebilmektedirler. Toplumun geleceği açısından önem arz eden üniversite öğrencisinin başarılı olması bilişsel zekası yanında duygusal zekasına da bağlıdır. Birey geliştirilebilir olan duygusal zekası sayesinde karşılaştığ1 zorluk ve engelleri aşabilecek, kendini motive edebilecek, çevresi ve arkadaşları ile güçlü bir iletişim kurabilecek ve bu sayede yaşamdan aldığı doyumu da arttıracaktır. Bireyin duygusal zekası sayesinde yaşam doyumunun artması ise bireyin başarıya daha kolay odaklanmasına ve akademik başarısının artmasına önemli katkılar sağlayabilecektir. Tüm bunların öneminden hareketle bu çalışmanın hedef kitlesini üniversite öğrencileri oluşturmakta olup, araştırma verilerini oluşturmak açısından İIBF İşletme, İktisat, Kamu Yönetimi ve Uluslararası İlişkiler öğrencileri araştırma örneklemini oluşturmuştur. Bu sayede öğrencilerin duygusal zekalarının, yaşam doyumu ve akademik başarıları üzerindeki etkilerinin incelenmesinin yanısıra öğrencilerin eğitim aldıkları bölümler bazında anlamlı bir farklılığa sahip olup olmadığı belirlenecek ve öneriler sunulacaktır. Bu çalışmada yalnızca İİF ve bağ $l_{1}$ bölümlerdeki öğrenciler örnekleme alınmış olup, şayet akademik bölüm farklılıkları araştırma değişkenleri açısından anlamlı farklılıklar oluşturursa, bir sonraki çalışmada öğrenciler sosyal bilimler, fen bilimleri, sağlık bilimleri ve eğitim bilimleri alanlarında örnekleme dahil edilerek oluşturulacak gruplarlarla, farklı bilim dallarındaki öğrencilerin algı farklılık veya benzerliği açığa çıkartılmaya çalışılacaktır.

\subsection{Araștırmanın Evreni ve Örneklem}

Araştırmanın evrenini; Kahramanmaraş Sütçü İmam Üniversitesi'nde öğrenim görmekte olan İktisadi ve İdari Bilimler Fakültesi 3. ve 4.sınıf İşletme, İktisat, Kamu Yönetimi ve Siyaset Bilimi ve Uluslar arası İlişkiler bölümleri öğrencileri oluşturmaktadır. 450 öğrenciye anket dağıtılmış olup 437 kullanılabilir anket elde edilmiş ve 437 öğrenci araştırmanın örneklemini oluşturmuştur.

\subsection{Araştırmanın Yöntemi}

Araştırmanın veri toplama aracı olarak anket yöntemi kullanılmıştır. Araştırmada kullanılan anket üç bölümden oluşmaktadır. Birinci bölümde; demografik özelliklerle ilgili sorular, ikinci bölümde; duygusal zekayı ölçmeye yönelik sorular, üçüncü bölümde ise öğrencilerin yaşam doyumlarını belirlemeye yönelik sorular yer almaktadır.

Duygusal zekayı ölçmek için Wong ve Law'ın (2002), Davis ve arkadaşlarının (1998) geliştirdiği dört boyuttan oluşan ölçek modeli kullanılmıştır. Bu ölçek Kendi Duygularını Değerlendirme, Başkalarının Duygularını Değerlendirme, Duyguların Kullanımı ve Duyguların Düzenlenmesi olmak üzere dört alt boyuttan oluşmaktadır.

Öğrencilerin yaşam doyumlarını belirlemeye yönelik olarak ise Diener, Emmons, Larsen ve Griffin (1985) tarafından geliştirilen ve Köker (1991) tarafından Türkçeye uyarlanan Yaşam Doyumu Ölçeği kullanılmıştır. Bu ölçek beş soru ve tek alt boyuttan oluşmaktadır. Akademik başarı ise öğrencilerin ağırlıklı genel not ortalamaları ile ölçülmüştür.

Anket uygulaması sonucu elde edilen veriler, SPSS programı kullanılarak; ANOVA, korelasyon ve regresyon analizlerine tabi tutularak araştırma hipotezleri test edilmiştir.

\subsection{Araștırmanın Modeli}

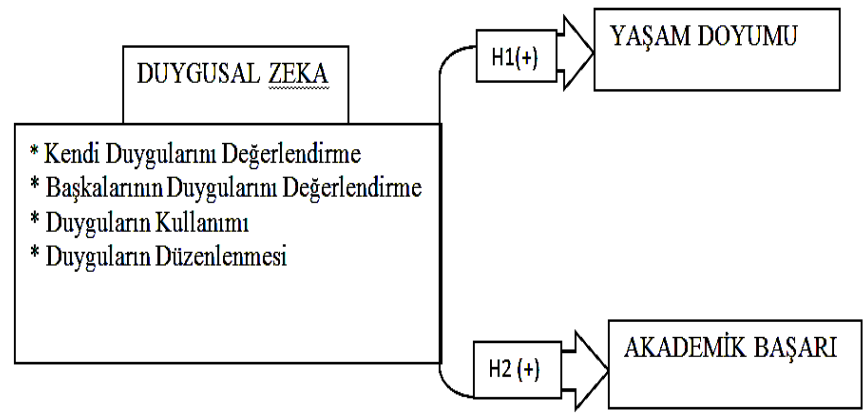

Araştırma modeli, duygusalzekanın bireyin yaşam doyumunu ve akademik başarısını olumlu yönde etkilediğini ifade etmektedir.

\subsection{Araştırmanın Hipotezleri}

Araştırmanın temel amacına yönelik olarak hipotezler şu şekilde belirlenmiştir;

H1: Duygusal zeka yaşam doyumunu pozitif yönde istatistiksel açıdan anlamlı olarak etkilemektedir.

H2: Duygusal zeka akademik başarıyı pozitif yönde istatistiksel açıdan anlamlı olarak etkilemektedir. 


\section{Araştırmaya İlişkin Bulgular Ve Yorumları}

$\mathrm{Bu}$ bölümde alan araştırmasından elde edilen verilerin istatistiksel analiz sonuçları yer almaktadır. Elde edilen analiz sonuçlarına göre bulguların yorumu yapılmıştır.

Tablo 1. Güvenilirlik Değerleri

\begin{tabular}{lc}
\hline Ölçekler & Alpha Değerleri \\
\hline Duygusal Zekâ &, 859 \\
Kendi Duygularını Değerlendirme &, 810 \\
Başkalarının Duygularını Değerlendirme &, 777 \\
Duyguların Kullanılması &, 816 \\
Duyguların Düzenlenmesi &, 809 \\
Yaşam Doyumu &, 777 \\
\hline
\end{tabular}

Tablo 1'de görüldüğü gibi duygusal zekâ ve alt boyutları ile yaşam doyumu ölçeğinin alfa katsayıları ,70'in üzerinde olduğu için güvenilirdir.

Tablo 2. Boyutların Ortalamaları

\begin{tabular}{lc}
\hline Boyutlar & Ortalama \\
\hline Kendi Duygularını Değerlendirme & $\mathbf{3 , 8 5 1 8}$ \\
Başkalarının Duygularını Değerlendirme & 3,7059 \\
Duyguların Kullanılması & 3,5578 \\
Duyguların Düzenlenmesi & $\mathbf{3 , 3 6 3 3}$ \\
Yaşam Doyumu & 3,3469 \\
\hline
\end{tabular}

Duygusal zeka ölçeğinin puanlandırılmasında beşli Likert tipi ölçek kullanılmıştır. Ölçek puanlamasında Hiçbir zaman:1, Bazen:2, Genellikle:3, Çoğu zaman:4, Her zaman:5 puan olarak değerlendirilmektedir. Buna göre duygusal zekâ boyutlarının ortalamaları incelendiğinde; "Kendi Duygularını Değerlendirme" boyutunun ortalamasının $(\mathbf{3 , 8 5})$ diğer boyutlara oranla daha yüksek olduğu görülmüştür. Öğrenciler kendi duygularınıdeğerlendirme konusunda diğer boyutlara nazaran daha iyiyken, duygularını düzenleme ve kontrol etme konusunda diğer boyutlara göre daha düşük bir ortalamaya $(\mathbf{3 , 3 6 )}$ sahiptir.

Yaşam doyumu boyutunun ölçek puanlamasında Kesinlikle katılmiyorum:1, Katılmıyorum:2, Karasızım:3, Kat1liyorum:4, Kesinlikle Katıliyorum:5 puan olarak değerlendirilmiştir. Buna göre; öğrencilerin yaşam doyumlarının aritmetik ortalaması 3,35 olarak bulunmuştur.

\section{Katılımcıların Demografik Özelliklerine İlişkin Bulgular;}

Tablo 3'te görüldüğü gibi anketlerden elde edilen demografik verilere göre; öğrencilerin $\% 53,5$ ' $\mathrm{i}$ kadın, \%46,5'i ise erkektir. \%47,6' işletme bölümü, \%22,7'si iktisat, \%21,1'i kamu yönetimi ve \%8,7'si uluslararası ilişkiler bölümünü öğrencileridir. $\% 32,3$ 'ü $3 . \quad$ sınıf öğrencileri, \% 67,7'si ise 4.sınıf öğrencileri olup \%53,1'i 1.öğretim, \%46,9'u 2. öğretimdir. Yaş dağılımları incelendiğinde \%74,4'ünün 19-23 arasında olduğu görülmektedir. Not ortalamalarına bakıldığında, \%49'unun not ortalaması 2-2,49 arasındadır. Öğrencilerin ailelerinin genel tutumlarına bakıldığında ise \%60,2 gibi bir çoğunluğun ailesinin demokratik bir tutum sergilediği görülmüştür. $\% 89,8$ 'inin anne ve babası evli birlikte yaşamakta, \%45,8'inin annesi ilkokul mezunu, \%35,2'sinin babası ise ilkokul mezunudur. Araştırmaya katılan öğrencilerin "en uzun süre yaşadığınız yer" sorusuna verdikleri yanıtlar incelendiğinde, \%33,9'u il, \%25,4'ü büyükșehir, \%24,7'sinin ise ilçede yaşadığı görülmektedir. 
Tablo 3. Katılımcıların Demografik Özellikleri

\begin{tabular}{|c|c|c|c|c|c|}
\hline Demografik Özellikler & Kişi sayısı & Yüzde & & Kişi sayısı & Yüzde \\
\hline Cinsiyet & & & Yaş & & \\
\hline Kadın & 234 & 53,5 & $19-21$ & 51 & 34,9 \\
\hline Erkek & 203 & 46,5 & $22-23$ & 246 & 39,5 \\
\hline Toplam & 437 & 100,0 & $24-25$ & 118 & 15,9 \\
\hline Sinıf & & & 26 ve üzeri & 22 & 7,7 \\
\hline 3.Sinıf & 141 & 32,3 & Toplam & 437 & 100,0 \\
\hline 4.Sinıf & 296 & 67,7 & Ağırlıklı Genel Not Ortalama & & \\
\hline Toplam & 437 & 100,0 & $1-1,99$ & 103 & 23,5 \\
\hline Bölüm & & & $2-2,49$ & 241 & 49,0 \\
\hline İşletme & 208 & 47,6 & $2,50-2,99$ & 96 & 22,0 \\
\hline İktisat & 99 & 22,7 & 3 ve üzeri & 24 & 5,5 \\
\hline Kamu Yönetimi & 92 & 21,1 & Toplam & 437 & 100,0 \\
\hline Uluslararası İlişkiler & 38 & 8,7 & Aile Tutumu & & \\
\hline Toplam & 437 & 100,0 & Otoriter & 160 & 36,6 \\
\hline Öğretim Türü & & & Demokratik & 263 & 60,2 \\
\hline 1.Öğretim & 232 & 53,1 & İlgisiz & 14 & 3,2 \\
\hline 2.Öğretim & 205 & 46,9 & Toplam & 437 & 100,0 \\
\hline Toplam & 437 & 100,0 & Anne Eğitim Durumu & & \\
\hline Anne baba medeni durum & & & Okuryazar değil & 69 & 15,8 \\
\hline Boşanmış ayrı yaşıyor & 10 & 2,3 & İlkokul & 200 & 45,8 \\
\hline Evli birlikte yaşıyor & 393 & 89,8 & Ortaokul & 68 & 15,6 \\
\hline Anne vefat etti & 3 & 0,7 & Lise & 71 & 16,2 \\
\hline Baba vefat etti & 27 & 6,2 & Ön Lisans & 9 & 2,1 \\
\hline Anne baba vefat etti & 4 & 0,9 & Lisans & 15 & 3,4 \\
\hline Toplam & 437 & 100,0 & Lisansüstü & 5 & 1,1 \\
\hline Baba Eğitim Durumu & & & Toplam & 437 & 100,0 \\
\hline Okuryazar değil & 17 & 3,9 & En uzun süre yaşadığınız yer & & \\
\hline İlkokul & 154 & 35,2 & Köy & 50 & 11,4 \\
\hline Ortaokul & 75 & 17,2 & Kasaba & 20 & 4,6 \\
\hline Lise & 117 & 26,8 & İlçe & 108 & 24,7 \\
\hline Ön Lisans & 22 & 5,0 & İl & 148 & 33,9 \\
\hline Lisans & 45 & 10,3 & Büyükşehir & 111 & 25,4 \\
\hline Lisansüstü & 7 & 1,6 & Toplam & 437 & 100,0 \\
\hline Toplam & 437 & 100,0 & & & \\
\hline
\end{tabular}

\section{Araştırma Hipotezlerinin Testine İlişkin Bulgular;}

Araştırmanın temel amacı olan, duygusal zekanın yaşam doyumu (H1) ve akademik başarı (H2) üzerindeki etkilerini incelemek için öncelikle korelasyon analizi yapılarak

\section{Korelasyon Analizi Sonuçları;}

Tablo 4. Duygusal Zekâ, Yaşam Doyumu ve Akademik Başarı Arasındaki İlișkiler

\begin{tabular}{|c|c|}
\hline Kendi Duygularını Değerlendirme & PearsonCorrelation \\
\hline Sig. & \\
\hline $\begin{array}{l}\text { Başkalarının Duygularını Değerlendirme } \\
\text { Sig. }\end{array}$ & PearsonCorrelation \\
\hline $\begin{array}{l}\text { Duyguların Kullanılması } \\
\text { Sig. }\end{array}$ & PearsonCorrelation \\
\hline $\begin{array}{r}\text { Duyguların Düzenlenmesi } \\
\text { Sig. }\end{array}$ & PearsonCorrelation \\
\hline Yaşam Doyumu & PearsonCorrelation \\
\hline
\end{tabular}

bağımlı değişkenleri olan yaşam doyumu ve akademik başarı araştırma değişkenleri arasındaki ilişkiler incelenmiş, daha sonra regresyon analizi ile bağımsız değişkenin (duygusal zeka) bağımlı değişkenler (yaşam doyumu ve akademik başarı) üzerindeki etki düzeyleri açığa çıkartılmıştır. arasındaki ilişkiyi açığa çıkartmak için korelasyon analizi yapılmıştır. Korelasyon analizi sonuçlarına göre duygusal 
zekanın dört alt boyutu ile yaşam doyumu arasında istatistiksel olarak anlamlı $(\mathrm{p}<, 001)$ ve pozitif bir ilişki olduğu, ancak akademik başarı ile aralarında anlamlı ilişkiler olmadığ1 bulgusuna ulaşılmıştır. Dolayısıyla, korelasyon analizi bulguları araştırmanın birinci hipotezini (H1) doğrular yönde çıkmış iken araştırmanın ikinci hipotezini (H2) destekler yönde değildir.

\section{Regresyon Analizi Sonuçları;}

Tablo 5. Duygusal Zekânın Yaşam Doyumuna Etkileri

\begin{tabular}{|c|c|c|c|c|c|}
\hline Model & Bağımsız Değişkenler & Bağımlı Değişken & Adjusted R ${ }^{2}$ & $\boldsymbol{\beta}$ & $\mathbf{P}$ \\
\hline \multirow[t]{5}{*}{1} & Kendi Duygularını Değerlendirme & & & 059 & ,269 \\
\hline & Başkalarının Duygularını Değerlendirme & Yaşam Doyumu &, 156 & 0,59 & ,228 \\
\hline & Duyguların Kullanılması & & & ,273 &, 000 \\
\hline & Duyguların Düzenlenmesi & & & ,121 & ,018 \\
\hline & $\mathbf{F}=21,075$ Sig. $=, 000$ & & & & \\
\hline
\end{tabular}

Regresyon analizi sonucuna göre;

Adjusted $\mathrm{R}^{2}$ determinasyon katsayısına göre, yaşam doyumundaki değişkenliğin \%15,6'sının duygusal zekanın iki bağımsız değişkeni olan duyguların kullanılması ( $\beta:, 273$, $\mathrm{p}<, 001)$ ve duyguların düzenlenmesi $(\beta:, 121, \quad \mathrm{p}<, 05)$ tarafından açıklandığı anlaşılmaktadır. Bağımlı ve bağımsız değişkenler arasındaki tüm ilişkiler anlamlı değildir. Analiz sonuçlarına göre; öğrencilerin kendi duygularını kullanıp iç motivasyonlarını sağlaması yaşam doyumlarını da pozitif yönde $(\beta=, 273, p .=000)$ etkilemektedir. Ayrıca öğrencilerin kendi duygularının kontrolünü sağlayıp onları düzenlemesi yine yaşam doyumlarını da pozitif yönde $(\beta=, 121, \mathrm{p}=018)$ etkilediği görülmüştür. Bunun yanı sıra öğrencilerin kendi duygularını ve başkalarının duygularını anlayıp değerlendirmesinin yaşam doyumlarını istatistiksel olarak anlamlı düzeyde etkilemediği sonucuna ulaşılmıştır.

Dolayısıyla $\mathbf{H 1}$ hipotezi kısmen kabul edilmiştir.

Tablo 6. Duygusal Zekânın Akademik Başarıya Etkileri

\begin{tabular}{|c|c|c|c|c|c|}
\hline Model & Bağımsız Değişkenler & Bağımlı Değişken & Adjusted $\mathbf{R}^{2}$ & $\boldsymbol{\beta}$ & $\mathbf{P}$ \\
\hline \multirow[t]{5}{*}{1} & Kendi Duygularını Değerlendirme & & &,- 042 & ,473 \\
\hline & Başkalarının Duygularını Değerlendirme & Akademik Başarı &,- 003 &,- 035 &, 513 \\
\hline & Duyguların Kullanılması & & & 082 &, 162 \\
\hline & Duyguların Düzenlenmesi & & &,- 008 & ,886 \\
\hline & $\mathbf{F}=, 622$ Sig. $=, 647$ & & & & \\
\hline
\end{tabular}

Tablo 6'daki regresyon analizi sonucuna göre duygusal zekanın akademik başarıyı istatistiksel olarak anlamlı düzeyde etkilemediği görülmüştür. Bütün istatistiksel anlamlılık değerleri ,05'ten büyük olduğu için, duygusal

Tek Yönlü ANOVA Analiz Sonuçları;

Tablo 7. Öğrencilerin Okudukları Bölüm İle Yaşam Doyumlarının Karșılaștırılmas

\begin{tabular}{|c|c|c|c|c|c|c|}
\hline & Bölüm & Sayı & Ortalama & Standart Sapma & $\mathbf{F}$ & P. \\
\hline \multirow{4}{*}{ Yaşam Doyumu } & İşletme & 208 & 3,45 & ,74891 & \multirow{4}{*}{4,248} & \multirow{4}{*}{,006 } \\
\hline & İktisat & 99 & 3,33 & ,77090 & & \\
\hline & Kamu Yönetimi & 92 & 3,09 & 96872 & & \\
\hline & Uluslararası İlişkiler & 38 & 3,44 &, 83550 & & \\
\hline \multicolumn{7}{|c|}{ Post Hoc Test (Tukey HSD) } \\
\hline & Bölüm & \multicolumn{2}{|c|}{ Bölüm } & Ortalama Farkı & \multicolumn{2}{|r|}{$\mathbf{P}$} \\
\hline Yaşam Doyumu & İşletme & \multicolumn{2}{|c|}{ Kamu Yönetimi } & ,35556 & \multicolumn{2}{|r|}{, 003} \\
\hline
\end{tabular}

zekanın akademik başarı üzerinde anlamlı bir etkisinin olduğunu söylemek mümkün değildir.

Dolayısıyla $\mathbf{H 2}$ hipotezi reddedilmiştir. Araştırma verileri ve bu örneklemi açısından duygusal zeka akademik başarıyı etkilememektedir.

Yukarıda yapılan ANOVA analizi sonucuna göre; öğrencilerin okudukları bölüm ile yaşam doyumları karşılaştırıldığında anlamlı bir farklılık bulunmuştur $(\mathrm{p}=0,006)$. Anlamlı farklılığın nereden kaynaklandığını bulmak için ise Tukey analizi yapılmıștır. Tukey analizi sonucuna göre, anlamlı farklılık işletme ve kamu yönetimi öğrencilerinden kaynaklanmaktadır. Buna göre; işletme bölümü öğrencilerinin kamu yönetimi bölümünde okuyan ögrencilere göre yaşam doyumlarının daha fazla olduğu görülmüştür. 
Tablo 8. Öğrencilerin Okudukları Bölüm İle Duygusal Zekalarının Karşılaştırılması

\begin{tabular}{|c|c|c|c|c|c|c|}
\hline & Bölüm & Sayı & Ortalama & Standart Sapma & $\mathbf{F}$ & $\mathbf{P}$ \\
\hline \multirow{4}{*}{ Duygusal Zeka } & İşletme & 208 & 3,66 & ,56609 & \multirow{4}{*}{,915 } & \multirow{4}{*}{,434 } \\
\hline & İktisat & 99 & 3,59 & ,62553 & & \\
\hline & Kamu Yönetimi & 92 & 3,55 & ,64308 & & \\
\hline & Uluslararası İlişkiler & 38 & 3,68 &, 58465 & & \\
\hline
\end{tabular}

Yapılan analiz sonucu öğrencilerin okudukları bölüm ile duygusal zekaları karşılaştırıldığında anlamlı bir farklılık bulunmamıştır.

Tablo 9. Öğrencilerin Ailelerinin Tutumu İle Yaşam Doyumlarının Karşılaştırılması

\begin{tabular}{|c|c|c|c|c|c|c|}
\hline & Aile Tutumu & Sayı & Ortalama & Standart Sapma & $\mathbf{F}$ & $\mathbf{P}$ \\
\hline & Otoriter & 160 & 3,21 &, 80151 & & \\
\hline \multirow[t]{2}{*}{ Yaşam Doyumu } & Demokratik & 263 & 3,45 & ,82627 & 6,705 & ,001 \\
\hline & İlgisiz & 14 & 2,90 & ,82112 & & \\
\hline \multicolumn{7}{|c|}{ Post Hoc Test (Tukey HSD) } \\
\hline & Aile Tutumu & \multicolumn{2}{|c|}{ Aile Tutumu } & Ortalama Farkı & & $\mathbf{P}$ \\
\hline \multirow[t]{2}{*}{ Yaşam Doyumu } & Otoriter & \multicolumn{2}{|c|}{ Demokratik } & \multicolumn{2}{|l|}{,- 24399} & ,008 \\
\hline & Demokratik & \multicolumn{2}{|c|}{ İlgisiz } & \multicolumn{2}{|l|}{, 55399} & 035 \\
\hline
\end{tabular}

ANOVA analizi sonucuna göre; öğrencilerin ailelerinin genel tutumları ile yaşam doyumları karşılaştırıldı ğında anlamlı bir farklılık bulunmuştur $(p=0,001)$. Anlamlı farklılığın nereden kaynaklandığını bulmak için ise Tukey

analizi yapılmıştır. Tukey analizi sonucuna göre, aile tutumu demokratik olan bireylerin yaşam doyumlarının, aile tutumu otoriter ve ilgisiz olanlara göre daha fazla olduğu belirlenmiştir.

Tablo 10. Öğrencilerin Ailelerinin Tutumu İle Duygusal Zekalarının Karşılaştırılması

\begin{tabular}{llccccc}
\hline & Aile Tutumu & Sayı & Ortalama & Standart Sapma & F & P \\
\hline \multirow{3}{*}{ Duygusal Zeka } & Otoriter & 160 & 3,61 &, 60143 & \\
& Demokratik & 263 & 3,63 &, 59847 &, 090 & \multirow{2}{*}{, 914} \\
& Illgisiz & 14 & 3,59 &, 59024 & & \\
\hline
\end{tabular}

Yapılan analiz sonucuna göre; duygusal zeka ile öğrencilerin aile tutumu karşılaştırıldığında anlamlı bir farklılık bulunmamıştır.

Tablo 11. Anne Baba Medeni Durumu İle Öğrencilerin Duygusal Zekalarının Karşılaştırılması

\begin{tabular}{|c|c|c|c|c|c|c|}
\hline & Anne Baba Medeni Durum & Sayı & Ortalama & Standart Sapma & $\mathbf{F}$ & $\mathbf{P}$ \\
\hline \multirow{5}{*}{ Duygusal Zeka } & Boşanmış ayrı yaşıyor & 10 & 3,60 &, 42919 & \multirow{5}{*}{,207 } & \multirow{5}{*}{,934 } \\
\hline & Evli birlikte yaşıyor & 393 & 3,62 & 60609 & & \\
\hline & Anne vefat etti & 3 & 3,88 & ,47186 & & \\
\hline & Baba vefat etti & 27 & 3,64 & 56677 & & \\
\hline & Anne baba vefat etti & 4 & 3,77 & 62993 & & \\
\hline
\end{tabular}

Yapılan analiz sonucuna göre; öğrencilerin anne babalarının medeni durumu ile duygusal zekaları karşılaştırıldığında anlamlı bir farklılık bulunmamıştır.

Tablo 12. Anne Baba Medeni Durumu İle Öğrencilerin Yaşam Doyumlarının Karşılaştırılması

\begin{tabular}{|c|c|c|c|c|c|c|}
\hline & Anne Baba Medeni Durum & Sayı & Ortalama & Standart Sapma & $\mathbf{F}$ & $\mathbf{P}$ \\
\hline \multirow{5}{*}{ Yaşam Doyumu } & Boşanmış ayrı yaşıyor & 10 & 2,72 & 82839 & \multirow{5}{*}{1,846} & \multirow{5}{*}{119} \\
\hline & Evli birlikte yaşıyor & 393 & 3,38 & 80944 & & \\
\hline & Anne vefat etti & 3 & 3,27 & ,46188 & & \\
\hline & Baba vefat etti & 27 & 3,21 & ,92733 & & \\
\hline & Anne baba vefat etti & 4 & 3,15 & 1,03763 & & \\
\hline
\end{tabular}

Yapılan analiz sonucuna göre; öğrencilerin anne babalarının medeni durumu ile yaşam doyumları karşılaştırıldığında anlamlı bir farklılık bulunmamıştır.

Tablo 13. En Uzun Süre Yaşanılan Yer İle Öğrencilerin Duygusal Zekalarının Karşılaştırılması

\begin{tabular}{llccccc}
\hline & En uzun süre yaşanılan yer & Sayı & Ortalama & Standart Sapma & F & P \\
\hline \multirow{6}{*}{ Duygusal Zeka } & Köy & 50 & 3,57 &, 56971 & & \\
& Kasaba & 20 & 3,68 &, 60204 &, 755 \\
& İlçe & 108 & 3,70 &, 60569 &, 595 \\
& İl & 148 & 3,60 &, 59248 & \\
& Büyükşehir & 111 & 3,58 &, 61212 & \\
\hline
\end{tabular}


Yapılan analiz sonucuna göre en uzun süre yaşanılan yer ile öğrencilerin duygusal zekaları arasında anlamlı bir farklılık bulunmamıştır.

Tablo 14. En Uzun Süre Yaşanılan Yer İle Öğrencilerin Yaşam Doyumlarının Karşılaştırılması

\begin{tabular}{|c|c|c|c|c|c|c|}
\hline & En uzun süre yaşanılan yer & Sayı & Ortalama & Standart Sapma & $\mathbf{F}$ & $\mathbf{P}$ \\
\hline \multirow{5}{*}{ Yaşam Doyumu } & Köy & 50 & 3,29 & 84969 & \multirow{5}{*}{, 518} & \multirow{5}{*}{, 72} \\
\hline & Kasaba & 20 & 3,13 &, 80072 & & \\
\hline & İlçe & 108 & 3,38 & ,84354 & & \\
\hline & İl & 148 & 3,34 &, 84739 & & \\
\hline & Büyükş̧ehir & 111 & 3,39 & ,75865 & & \\
\hline
\end{tabular}

Yapılan analiz sonucuna göre en uzun süre yaşanılan yer ile öğrencilerin yaşam doyumları arasında anlamlı bir farklılık bulunmamıștır.

T-Testi Analizi Sonuçları;

Tablo 15. Öğrencilerin Cinsiyet, Sınıf, Öğretim Türü ile Yaşam Doyumlarının Karşılaştırılması

\begin{tabular}{|c|c|c|c|c|c|c|}
\hline & & Sayı & Ortalama & Standart Sapma & $\mathbf{T}$ & $\mathbf{P}$ \\
\hline \multirow[t]{2}{*}{ Cinsiyet } & Kadın & 234 & 3,38 & ,81786 &, 867 & ,387 \\
\hline & Erkek & 203 & 3,31 &, 82537 & & \\
\hline \multirow[t]{2}{*}{ Sinıf } & 3.Sinif & 141 & 3,40 & ,75119 & ,958 & ,339 \\
\hline & 4.Sinif & 296 & 3,32 &, 85241 & & \\
\hline \multirow[t]{2}{*}{ Öğretim Türü } & 1.Öğretim & 232 & 3,33 & ,84167 &,- 336 & ,737 \\
\hline & 2.Öğretim & 205 & 3,36 & ,79904 & & \\
\hline
\end{tabular}

Yukarıda yapılan T-Testi analizi sonuçlarına göre öğrencilerin cinsiyeti, sınıfı ve öğretim türü ile yaşam doyumları karşılaştırıldığında anlamlı bir farklılık bulunmamıştır.

Tablo 16. Öğrencilerin Cinsiyet, Sınıf, Öğretim Türü ile Duygusal Zekalarının Karşılaştırılması

\begin{tabular}{|c|c|c|c|c|c|c|}
\hline & & Sayı & Ortalama & Standart Sapma & $\mathbf{T}$ & $\mathbf{P}$ \\
\hline \multirow[t]{2}{*}{ Cinsiyet } & Kadın & 234 & 3,56 & ,61207 & $-2,217$ & ,027 \\
\hline & Erkek & 203 & 3,69 &, 57555 & & \\
\hline \multirow[t]{2}{*}{ Sinıf } & 3.Sinif & 141 & 3,60 & 60983 &,- 535 & ,593 \\
\hline & 4.Sinif & 296 & 3,63 &, 59312 & & \\
\hline \multirow[t]{2}{*}{ Öğretim Türü } & 1.Öğretim & 232 & 3,65 &, 57435 & 1,129 & ,260 \\
\hline & 2.Öğretim & 205 & 3,59 & ,62343 & & \\
\hline
\end{tabular}

Yapılan T-Testi analizi sonuçlarına göre öğrencilerin cinsiyetleri ile duygusal zekaları arasında anlamlı bir farklılık bulunmuştur ( $p<, 005)$.| Buna göre erkeklerin duygusal zekalarının $(3,69)$ kadınlara göre daha fazla olduğu görülmüştür $(3,56)$. Fakat öğrencilerin sınıfı ve öğretim türü ile duygusal zekaları arasında anlamlı bir farklılık bulunmamıştır.

\section{Sonuç Ve Öneriler}

Duygusal zekanın yaşam doyumuna ve akademik başarıya etkilerinin incelendiği bu çalışmada; duygusal zeka boyutlarından "Duyguların Kullanımı" ve "Duyguların Düzenlenmesi” boyutlarının öğrencilerin yaşam doyumlarını pozitif yönde etkilediği görülmüştür. Ancak, duygusal zeka boyutlarından"Kendi Duygularını Anlama" ve "Başkalarının Duygularını Anlama" boyutlarının öğrencilerin yaşam doyumlarını etkilemediği belirlenmiştir. Ayrıca öğrencilerin duygusal zekalarının akademik başarılarını etkilemediği sonucuna ulaşılmıştır. Bu sonuç Kavcar (2011) ve Üzel ve Hangül'ün (2011) yaptıkları çalışmalar ile paralellik göstermemiştir. $\mathrm{Bu}$ yazarların çalışmalarında duygusal zekanın akademik başarıyı etkilediği görülürken bu çalışmada böyle bir etki bulunmamıştır.

Duygusal zekanın tüm alt boyutları ile yaşam doyumu arasında pozitif ve anlamlı ilişkiler bulunurken, akademik başarı arasında anlamlı ilişki bulunmamıştır. Duygusal zeka ve yaşam doyumu arasındaki pozitif ve anlamlı ilişkiler Ergin ve ark. (2013) ve Deniz ve Yılmaz'ın (2004) çalışmaları ile paralellik göstermiştir. Bu sonuç doğrultusunda, öğrencilerin duygusal zeka düzeyleri arttıkça yaşam doyumlarının da arttığı söylenebilir.

Öğrencilerin kendi duygularını değerlendirme konusunda diğer duygusal zeka boyutlarına nazaran daha iyiyken, duygularını düzenleme ve kontrol etme konusunda ise diğer boyutlara göre nazaran daha zayıftırlar.

İşletme bölümü öğrencilerinin kamu yönetimi bölümünde okuyan öğrencilere göre yaşam doyumlarının daha fazla olduğu görülmüştür. Aile tutumu demokratik olan bireylerin de yaşam doyumlarının aile tutumu otoriter ve ilgisiz olan bireylere göre daha fazla olduğu belirlenmiştir. Bunların yanı sıra anne baba medeni durumu ve en uzun süre yaşanılan yer ile öğrencilerin yaşam doyumları arasında anlamlı bir farklılık görülmemiştir.

Öğrencilerin okudukları bölüm, aile tutumu, anne baba medeni durumu ve en uzun süre yaşanılan yer ile öğrencilerin duygusal zekaları anlamlı bir farklılık göstermemektedir.

Öğrencilerin sınıfları ve öğretim türlerine göre de duygusal zekaları ve yaşam doyumları farklılaşmamaktadır. Fakat öğrencilerin cinsiyetleri ile duygusal zekaları arasında anlamlı bir farklılık vardır. 
$\mathrm{Bu}$ sonuçlara göre; öğrencilerin yaşam doyumlarının sağlanmasında özellikle kendi duygularını kontrol edip onu amaçları yönünde kullanarak kontrol edebilmesinin yaşam doyumlarını önemli ölçüde etkilediği sonucuna ulaşıldığından dolayı; öğrencilerin geliştirilebilir olan duygusal zekalarını bu yönde kullanıp yaşam doyumlarını arttırabilecekleri söylenebilir. Bunu başarabilmenin bir yolu da araştırma sonuçlarında bulunan ailelerin demokratik tutum sergilemeleridir. $\mathrm{Bu}$ yüzden aileler çocuklarına karşı demokratik bir tutum içinde olmaya özen göstermelidir. Çünkü yaşam doyumu sağlamış bir birey hem aileler için hem toplum için çok önemlidir. Üniversite yıllarından itibaren bu doyumun sağlanması bireyin gelecek yaşamını da olumlu etkileyecektir.

Araştırma sonuçlarına göre işletme bölümü öğrencilerinin kamu yönetimi bölümündeki öğrencilere göre yaşam doyumlarının daha fazla olduğu görülmüştür. Öğrencilerin akademik eğitim aldıkları bölümlerin yaşam doyumlarında bir farklılığa yol açmasının nedenleri bir başka araştırmada ele alınarak incelenmelidir.

Birey duygusal zekasını kullanmak için öncelikle kendini tanımalıdır. Kendini tanımayan bir bireyin başkasını anlaması ve tanıması zordur. Kendini tanıyan birey, başkalarını tanımada ve duygularını kullanmada daha başarılı olacaktır ve yaşam doyumu artacaktır.

$\mathrm{Bu}$ çalışmamızda duygusal zekanın akademik başarıyı etkilemediği görülmüştür. Ancak bu çalışmanın tek bir üniversitede ve sadece İ̈BF bölümlerindeyapılması araştırmanın sınırlılığını oluşturmaktadır. Daha genellenebilir bir sonuç vermek adına başka üniversitelerde, başka bölümlerde ve başka enstitülerde de bu etki araştırılabilir.

\section{Kaynaklar}

Brackett, M.,Rivers, S.E. ve Salovey, P.(2011), "Emotional Intelligence: Implications for Personal, Social, Academic, and Workplace Success", Social and Personality Psychology Compass, 5(1), 88-103.

Carter, V.ve Good, E. (1973), Dictionary of Education, McGraw Hill Book Company, New York.

Cooper, R.K.Sawaf. A.(2003), Liderlikte Duygusal Zeka, Sistem Yayıncılık, İstanbul.

Çakar, U., ve Arbak, Y.(2004), "Modern Yaklaşımlar Işığında Değişen Duygu-ZekaIllişkisi ve Duygusal Zeka", Dokuz Eylül Üniversitesi Sosyal Bilimler Enstitüsü Dergisi, 6(3), 23-48.

Çapraz, B.Kesken, J.Ayyıldız, N. ve İlic, D.(2009), "Yönetsel Zeka'ya Doğru: Yönetsel Zeka ve Bileşenlerini Tanımlamaya Yönelik Kavramsal Bir Çalışma”, Ege Akademik Bakış, 9(1), 187-211.

Çivitvi, A. (2012), “Üniversite Öğrencilerinde Genel Yaşam Doyumu ve Psikolojik İhtiyaçlar Arasındaki İlişkiler", Çukurova Üniversitesi Sosyal Bilimler Enstitüsü Dergisi, 21(2), 321-336.

Deniz, M.E. ve Y1lmaz, E.(2004), “Üniversite Öğrencilerinin Duygusal Zeka Yetenekleri ve Yaşam Doyumları", XIII. Ulusal Eğitim Bilimleri Kurultayı.

Diener,E., Emmons, R. A., Larsen, R. J. ve Griffin, S. (1985). "The Satisfaction With Life Scale", Journal Of Personality Assesment, 49 (1), 71-75.
Doğan, S. (2005), Çalışan İlişkileri Yönetimi, Kare Yayınlar1, İstanbul.

Dost, M.T.(2007), "Üniversite Öğrencilerinin Yaşam Doyumlarının Bazı Değişkenlere Göre İncelenmesi", Pamukkale Üniversitesi Eğitim Fakültesi Dergisi, (2), 132143.

Drago, J.M.(2004), The Relationship Between Emotional Intelligence and Academic Achievement in Nontraditional College Students, Doktora Tezi, Walden University.

Druskat,et al.(2006), Linking Emotional Intelligence And Performance At Work Current Research Evidence with Individuals and Groups, Lawrence Erlbaum Associates, Publishers, Mahwah, New Jersey London.

Ergin, B.Kaynak, B.Pınarcık, Ö. ve Arslan, E.(2013), “Okul Öncesi Öğretmen Adaylarının Duygusal Zekaları ve Yaşam Doyumları Arasındaki İlișki”, Eğitim ve Öğretim Araştırmaları Dergisi, 2(2), 35-42.

Goleman, D.(1995), Emotional Intelligence, Bantam Books, New York.

Goleman, D. (2005), Duygusal Zeka Neden IQ'dan Daha Önemlidir? (çev. B.S.Yüksel), Varlık Yayınları, İstanbul.

Green, A.L.(2000), “The Perceived Motivation for Academic Achievement Among African American College Students", The Florida State University.

Gürbüz, S. ve Yüksel, M.(2008), “Çalışma Ortamında Duygusal Zeka: İş Performansı, İş Tatmini, Örgütsel Vatandaşlık Davranışı ve Bazı Demografik Özelliklerle İlişkisi”, Doğuş Üniversitesi Dergisi, 9 (2), 174-190.

Holt, S.(2007), Emotional Intelligence and Academic Achievement in Higher Education, Doktora Tezi, Pepperdine University.

Karakaş, S. (1981), Psikolojiye Giriş Ders Kitabı, Hacettepe Üniversitesi Psikoloji Bölümü Yayınları, Ankara.

Kavcar, B.(2011), Duygusal Zeka İle Akademik Başarı Ve Bazı Demografik Değişkenlerin İlişkileri: Bir Devlet Üniversitesi Örneği, Doktora Tezi, Ankara Üniversitesi Sosyal Bilimler Enstitüsü, Ankara.

Kenarlı, Ö.(2007), Duygusal Zeka- Akademik Başarı Etkileşimine İlişkin Öğrenci Görüşlerinin Değerlendirilmesi. Yayımlanmış Yüksek Lisans Tezi, Dicle Üniversitesi Diyarbakır.

Keskin, G. ve Sezgin, B.(2009) "Bir Grup Ergende Akademik Başarı Durumuna Etki Eden Etmenlerin Belirlenmesi", Fırat Sağlık Hizmetleri Dergisi, 4(10), 3-18.

Köker, S.(1991), Normal ve Sorunlu Ergenlerin Yaşam Doyumu Düzeyinin Karşılaştırılması, Yayımlanmamış Yüksek Lisans Tezi, Ankara Üniversitesi Sosyal Bilimler Enstitüsü, Ankara.

Köknel, Ö.(1998), Dolu Dolu Yaşamak, Altın Kitaplar Yayınevi, İstanbul.

Matthews, G.,et al., (2002), Emotional Intelligence Science and Myth, Massachusetts, The MIT Press.

Mayer, J,D., et al.(2004), "Emotional Intelligence: Theory, Findings, and Implications", Psychological Inquiry, 15(3), 197-215.

Memduhoğlu, H.B. ve Yılmaz, K.(2010), "Yönetimde Yeni Yaklaşımlar”, Pegem Akademi, Ankara. 
Neugarten, B.Havighurst, R. ve Tobin, S. (1961),The Measure of Life Satisfaction. Journal of Gerontology, 16, 134-143.

NG, K.M.Wang, C.Zalaquett, C.P. ve Bodenhorn, N.(2007), "A Confirmatory Factor Analysis of the Wong and Law Emotional Intelligence Scale in a Sample of International College Students", Int J Adv Counselling, 29, 173-185.

Parthasarathy, R.(2009) "Emotional Intelligence and the Quality Manager Beauty and the Beast?", The Journal For Quality \& Participation January.

Rahim, M.A.ve Psenicka, C. (2002), “A Model Of Emotional Intelligence And Conflict Management Strategies: A Study In Seven Countries". The International Journal Of Organizational Analysis, 10(4), 302-326.

Recepoğlu, H.(2013), “Öğretmen Adaylarının Yaşam Doyumları ile Öğretmenlik Mesleğine İlişkin Tutumları”, Hacettepe Üniversitesi Eğitim Fakültesi Dergisi, (1), 311326.

Salovey, P. ve Mayer, J.D.(1990), "Emotional Intelligence", students at risk for school failure", Journal of Applied Psychology, 82, 221-234

Sung-Mook, H. ve Giannakopoulos, E. (1994), "The relationship of satisfaction with life to personality characteristics", Journal of Psychology Interdisciplinary \& Applied 128(5), 547-555.

Tekin Acar, F.,(2002), Duygusal Zeka Yeteneklerinin Göreve Yönelik Ve İnsana Yönelik Liderlik Davranışları İle İlişkisi: Banka Şube Müdürleri Üzerine Bir Alan Araştırması, Yayınlanmamış Doktora Tezi, İstanbul Üniversitesi, Sosyal Bilimler Enstitüsü, İstanbul.

Toktamışoğlu, M.(2003), Aklın Öteki Sesi-Duygusal Zekâyla Başarı, Kapital Yayıncılık, İstanbul.

Wong. C.S. ve Law, K.S. (2002), "Development of an emotional intelligence instrument and an investigation of its relationship with leader and follower performance and attitudes," TheLeadershipQuarterly, (13), 1-32.

Wong, C.S.Law, K.S.Wong, P.M.(2004), "Development and Validation of a Forced Choise Emotional Intelligence Measure for Chinese Respondents in Hong Kong, Asia Pacific Journal of Management”, 21(4), 535-559.

Üzel, D., ve Hangül, T.(2011), '’Duygusal Zeka ve Akademik Başarı Arasındaki İlişki’', Balıkesir.

Yeşilyaprak, B. (2001), Duygusal Zeka ve Eğitim Açısından Doğurguları. Kuram ve Uygulamada Eğitim Yönetimi, 7 (25), 139-146.

Yılmaz, S. (2007), Duygusal Zeka ve Akademik Başarı Arasındaki İlişki' Yayımlanmamış Yüksek Lisans Tezi, Atatürk Üniversitesi Sosyal Bilimler Enstitüsü, Erzurum. 